\title{
歯周病原菌に対するアクア酸化水の殺菌効果
}

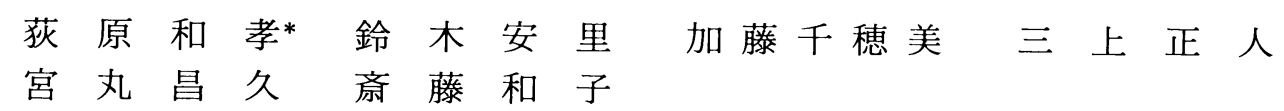

\section{Bactericidal Effect of Aqua Oxidizing Water Against Periodontopathic Bacteria}

\author{
Kazutaka Ogiwara* Anri Suzuki Chihomi Kato Masato Mikami \\ Masahisa Miyamaru and Kazuko Saito
}

There are many types of equipment of making acidic electrolyzed water from tap water. We utilized one of them : OXILYZER which is made by Miura Electric Co., Akita, Japan. Aqua oxidized water (AOW) is acidic water with a $\mathrm{pH}$ under 2.7 and is processed by electrolysis through a small $\mathrm{NaCl}$ mediated specific membrane. It has over $1,100 \mathrm{mV}$ of oxi-redx potential and includes $\mathrm{Cl}_{2}, \mathrm{OH} \cdot, \mathrm{O}_{3}$, $\mathrm{ClO}$.

This acidic water has a strong bactericidal effect to bacteria and virus but there are few reports concerning its bactericidal activity to periodontopathic bacteria. We investigated the bactericidal effect of AOW to periodontopathic bacteria, two strains of Actinobacillus actinomycetemcomitans $(\mathrm{Aa})$, two strains of Porphyromonas gingivalis ( $\mathrm{Pg}$ ) and a strain of Fusobacterium nucleatum ( $\mathrm{Fn}$ ). Staphylococcus aureus (Sa) 209 P, Escherichia coli (Ec) B and Salmonella enteritidis (Se) SER were used for comparison of the bactericidal activity of AOW to periodontopathic bacteria.

AOW was obtained from an OXILYZER and stored in a polyethilene bottle and kept in a dark cold place totally blocked from light.

Bacterial strain Aa : Y4 and ATCC 29522, Pg: 381 and ATCC 33277, Fn : ATCC 23726 were grown at $37^{\circ} \mathrm{C}$ in $\mathrm{BHI}\left(5 \% \mathrm{CO}_{2}\right)$, BHI contained hemin, menadion and yeast extract (anaerobic condition), and GAM broth (anaerobic condition), respectively. After washing by centrifugation, each bacteria was suspended in PBS and adjusted to the optical density of 0.3 at $540 \mathrm{~nm}$ light length with $0.1 \%$ gelatin containing Hanks' balanced salt solution (GHBSS).

Serum and saliva were obtained from volunteers of healthy student. Saliva was sterilized through a millipore filter with a $0.45 \mu \mathrm{m}$ pore size.

Bactericidal activity was performed by colony count seeding and grown on BHI or Anaero columbia blood agar or GAM medium after treatment with AOW.

The following results were obtained :

1. Bactericidal effect and effective concentration of AOW

Periodontopathic bacteria were AOW sensitive and were killed in one minute, from the original $25 \%$ AOW, while it needed more time and a higher concentration to kill Ec, Sa and Se.

日本歯科大学新潟歯学部口腔微生物学教室

*日本霜科大学歯学部歯周病学教室 
2. The effect of serum and saliva on bactericidal activity of AOW.

To $\mathrm{Aa}$ and $\mathrm{Pg}$, the addition of serum or saliva in a concentration of $1 \%$ of $\mathrm{AOW}$ had the effect of bactericidal activity. However, the bactericidal activity was completely lost by the addition of $10 \%$ serum in AOW. To Fn, the bactericidal effect was lost in only $1 \%$ of serum or $10 \%$ salivary addition.

3. Stability of bactericidal activity of AOW.

$\mathrm{AOW}$ was kept in a polyethilene bottle at $4^{\circ} \mathrm{C}$ with shading from light. The bactericidal activity was examined by withdrawing AOW from the shielded bottle weekly. The activity was well preserved until 5 months. After 21 weeks, a slight decrease of bactericidal activity was observed in $25 \%$ AOW

4. Cause of decrease of bactericidal activity by addition of $10 \%$ serum to AOW.

The addition of serum to AOW caused a decrease of oxi-red potential from 1144.8 to 479.0 . $\mathrm{pH}$ from 2.52 to 5.60 , and $\mathrm{HClO}$ from $19.4 \mathrm{ppm}$ to undetectable.

In conclusion, AOW is a useful disinfectant of periodontopathic bacteria in vitro. The oral environment is very complex. We must pay careful attention not only to the decrease of bactericidal activity of AOW by salivary flow and bleeding, but also the effect of AOW on the mucosa.

\section{緒言}

近年，食塩水を利用し隔膜を介して電気分解す ることで陽極側に得られる強電解水が，抗細菌・ 抗ウィルス効果を示すことが報告され ${ }^{1)}$, 歯科領 域に扔いてもその応用が期待されている.

また,アクア酸化水 (AOW) は OXILYSER(三 浦電子社製) から生成される強酸性水で, $\mathrm{pH}$ は 2.7 以下, 酸化還元電位は, $1,100 \mathrm{mV}$ 以上の高い ポテンシャルを有し, $\mathrm{Cl}_{2}, \mathrm{OH} ・, \mathrm{O}_{3}, \mathrm{ClO}$ などが 含まれており，これらが殺菌力を発揮するのに関 与すると考えられる。

現在まで，医科・歯科領域において AOW の細 菌, ウィルス, 真菌に対する殺菌効果が検討され， その殺菌効果のあることやプラーク抑制効果が報 告されている ${ }^{2 \sim 10)}$. しかし歯周病原菌に関する殺 菌の報告は見られない。

そこで本実験では，AOW の歯周病原菌に対す る殺菌力を検討し, 口腔内環境下で, その殺菌力 が保持されるかをあきらかにする目的で Staphylococcus aureus, Escherichia coli, Salmonella enteritidisを対照として, 歯周病原菌 Actinobacillus actinomycetemcomitans, Porphyr. omonas gingivalis, Fusobacterium nucleatum の $\mathrm{AOW}$ の殺菌効果について検討を加え,さらに
唾液・血清の添加による殺菌への影響を調べた。

\section{材料と方法}

\section{AOW の使用条件}

実験に使用した AOW は, 調整直後の酸化還元 電位 $1,100 \mathrm{mV}$ 以上, $\mathrm{pH} 2.5$ 付近のものでヨウ化 カリウム澱粉紙が青紫色に変色することを確認し てから実験に供した。

殺菌力の持続性を検討するため, 同条件の $\mathrm{AOW}$ をポリ容器に採取後, 遮光密封して $4{ }^{\circ} \mathrm{C} に$ て保存した。

\section{2. 使用菌株}

歯周病原菌として Actinobacillus actinomycetemcomitans（以下 $\mathrm{Aa}$ と略す） Y 4 株, ATCC 29522 株, Porphyromonas gingivalis (以下 Pg と略す) 381 株, ATCC 33277 株, Fusobacterium nucleatum (以下 Fn と略す) ATCC 23726 株, 対照細菌群として Staphylococcus aureus (以下 $\mathrm{Sa}$ と略す) $209 \mathrm{P}$ 株, Escherichia coli (以下 Ec と略す) B 株, Salmonella enteritidis (以下 Se と略す) SER 株の 6 菌種, 8 菌株を使 用した。 


\section{3. 菌の培養方法とその調製法}

$\mathrm{Aa}$ 群は, BHI 液体培地 (BBL. Co., USA) を 用い, $5 \% \mathrm{CO}_{2}, 95 \%$ Air の炭酸ガス培養器（ト キワ, 東京) 中で $37^{\circ} \mathrm{C}, 24$ 時間培養を行った。 $\mathrm{Pg}$ 群は, 1\% hemin (Sigma Co., USA), 0.02\% menadione (半井化学, 東京), $5 \%$ Yeast (Difco, USA）含有 BHI 液体培地を，Fnは GAM ブイ ヨン培地（ニッスイ，東京）をそれぞれ用い, AnaeroPack・ケンキ (三菱ガス化学, 東京) を 利用した嫌気条件下で $37^{\circ} \mathrm{C}, 24$ 時間培養を行っ た. Sa, Se, Ec は, BHI 液体培地を用い, 好気 条件下で $37^{\circ} \mathrm{C}, 24$ 時間培養を行った。

培養後, $10,000 \times \mathrm{g}, 10$ 分間遠心して集菌し, phosphate buffered saline (PBS) にて洗浄後, $0.1 \%$ gelatin (Difco) 含有 Hank's balanced salt solution (GHBSS) にて希釈し, 分光光度計 Spectronic 20 型 (島津製作所, 京都)を用い，540 $\mathrm{nm}$ の波長における optical density (O.D.) 0.3 の 菌懸濁液を調製した。

\section{4.血清および唾液の調製}

使用血清は, 臨床的に健康と思われるボラン ティア男子学生から末梢血を採取し, 室温にて凝 血させた後, 遠心上清を採取した。唾液は, 全唾 液採取後, $10,000 \times \mathrm{g}, 5$ 分間遠心分離した後の上 清を，ポア・サイズ $0.45 \mu \mathrm{m}$ のメンブラン・フィ ルターにてろ過滅菌したものを使用した。

\section{AOW の殺菌効果と希勫による影響}

反応液組成は, 実験群として AOW 原液抢よび 最終濃度 $50,25 \% \mathrm{AOW}$ 希釈液のそれぞれ $0.9 \mathrm{ml}$ に, O.D. 0.3 に調製した菌懸濁液 $0.1 \mathrm{~m} l$ を加え 全量を $1 \mathrm{~m} l$ とした。対照には，生理食塩水を使 用した。 反応は室温で行い, 反応開始 $1,5,10$ 分 後の反応液 $20 \mu l$ を採り増菌に使用した培地で連 続 10 倍希釈後, 寒天平板 Spot 法にて生菌数を求 めた. 寒天平板培地上に各希釈菌液を $10 \mu l$ 滴下, 前述培養条件で $2 \sim 4$ 日間培養後，得られたコロ ニー数を基に colony forming unit $/ \mathrm{m} l$ (生菌数) に換算し, 生理食塩液中の対照生菌数と比較して 判定した.

$\mathrm{Aa}$ 群, Sa, Ec, Se は 1.5\%寒天 (BBL. Co.) 含
有 BHI 寒天平板培地を, Pg 群が Anaero コロン ビア寒天平板培地 (BBL. Co.), Fn には GAM 寒 天平板培地（ニッスイ）をそれぞれ用いた。

\section{AOW の殺菌効果への血清および唾液の添加に よる影響}

AOW 原液の反応液に, 実験群として $1 \%$ ない しは $10 \%$ 相当量の血清または唾液を添加して生 菌数の変化を測定し, Aa 群, Pg 群, Fn に対す る $\mathrm{AOW}$ の殺菌効果への影響を生菌数にて検討 した.

\section{AOW の殺菌力の持続性について}

Aa Y 4 株を用い, 前述した条件で保存した AOW の殺菌効果と希䣋による影響を, 調製直後, 8 週間後, 15 週間後, 21 週間後と経時的に検討し た。

\section{AOW の性質について}

1 ) ラジカルの変化について

各条件下での AOW 中に含有されているラジ カルを，ルミノール依存性ケミルミネッセンス反 応 (CL 反応) を用い測定した。

$\mathrm{AOW}$ の各条件の反応液 $0.6 \mathrm{~m} l$ luminol solution（フタバ・メディカル東京） $0.05 \mathrm{ml}$ を加 えただちに Lumiphotometer TD 4000(フタバ・ メディカル)にて $37^{\circ} \mathrm{C} ， 1$ 秒間隔で経時的に測定 した。

2 ） $\mathrm{pH}$ および酸化還元電位の変化について

各条件下での $\mathrm{AOW}$ の $\mathrm{pH}$ と酸化還元電位を, 複合電極を使用し $\Phi 34 \mathrm{pH}$ メーター（Beckman, 東京）により測定した。

3 ) $\mathrm{AOW}$ の $\mathrm{HClO}$ 量について

各条件下での $\mathrm{AOW}$ の $\mathrm{HClO}$ 量を, ヨウ素一デ

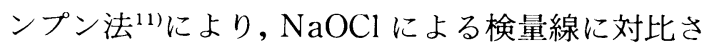
せて求めた。

\section{結果}

1. AOW の殺菌効果と希釈による影響

1) 対照細菌群に対する AOW の殺菌効果と希 釈による影響（表 1 ）。 
$\mathrm{AOW}$ 原液では, Sa と Ec を1 分以内に生残 菌 $10^{\S}$ から $10^{3}$ 以下へと著しく減少させた。しか し, Se に対しては, 生残菌 $10^{3}$ 以下に減少させる のに 1 分以上 5 分以内の時間を必要とした。

また AOW 50\%希釈液では, Ec と Se に対し $\mathrm{AOW}$ 原液と同様の傾向を示したが, Sa では 10 分後でも $10^{6}$ 個の菌が生残し，抵抗のあることを 示した。さらに AOW 25\%希釈液において, Ec は 1 分で $10^{3}$ 個に減少したが以後 10 分経過後もそ れ以上の減少を示さなかった. Sa と Seではほと んどの菌が 10 分後でも生残していた。

2 ) 歯周病原菌に対する AOW の殺菌効果と希 釈による影響（表 2)

AOW 原液では, Aa 群, Pg 群, Fn の 3 菌種 とも生残菌が 1 分以内に $10^{8}$ から $10^{3}$ 以下にと著 しい減少を認め,さらに AOW 25\%希釈液でも $\mathrm{Aa}$ 群と Pg 群, Fn で, 1 分以内に生残菌が $10^{3}$ 以下と著しい滅少を示した。

\section{AOW の殺菌効果への血清および唾液の影響}

(表 3 )

1) $\mathrm{AOW}$ の殺菌効果への血清添加の影響

血清 $1 \%$ の添加では, Aa 29522 株や Pg 群を 1 分以内に生残菌 $10^{8}$ から $10^{3}$ 以下に減少させた
が, Aa Y4 株には生残菌 $10^{3}$ 以下の減少を得るの に 1 分以上 5 分間の時間を必要とした。また，Fn に対しては血清 $1 \%$ の添加により10 分後でも $10^{6}$ 個の菌が生残した。

さらに, 血清 $10 \%$ の添加では, 3 菌種とも生残 菌の減少を認めなかった。

2 ) $\mathrm{AOW}$ の殺菌効果への唾液添加の影響

唾液 10\%添加により, Aa 群や Pg 群に対して は 1 分以内に生残菌が $10^{3}$ 以下と著しい減少を示 したが，Fn では 10 分後でも $10^{5}$ 個の菌が生残し ていた。

\section{AOW の殺菌力の持続性（表 4)}

ポリ容器に採取後, 遮光密封して $4{ }^{\circ} \mathrm{C} て ゙$ 保存し た AOW について, Aa Y4 を用いて調製直後か ら経時的に 21 週後までの殺菌力を検討した。その 結果, 21 週後でも調製直後と同様, AOW 原液お よび $50 \%$ 希釈液では 1 分以内に生残菌が $10^{3}$ 個以 下となる著しい減少が認められた.しかし, 21 週 後 AOW 25\%希釈液では生残菌が $10^{3}$ 以下に減少 するには 1 分以上 5 分以内の時間を必要とした。

\section{4. 各条件下での AOW の性質}

1) CL 反応ラジカルの変化 (図 1 )

表 1 S. aureus, E. coli, S. enteritidis に対する AOW の殺菌効果と希釈による影響

\begin{tabular}{|c|c|c|c|c|c|}
\hline \multirow{2}{*}{ 細菌の種類 } & \multirow{2}{*}{ AOW 濃度 } & \multicolumn{4}{|c|}{ 生残菌数（個） } \\
\hline & & $0 \mathrm{~min}$ & $1 \mathrm{~min}$ & $5 \mathrm{~min}$ & $10 \mathrm{~min}$ \\
\hline \multirow{4}{*}{$\begin{array}{l}\text { S. aureus } \\
(\mathrm{Sa})\end{array}$} & 生理食塩液 & \multirow{4}{*}{$2.0 \times 10^{8}$} & $2.0 \times 10^{8}$ & $1.9 \times 10^{8}$ & $2.2 \times 10^{8}$ \\
\hline & AOW（原液） & & $1.0 \times 10^{3} \downarrow$ & $1.0 \times 10^{3} \downarrow$ & $1.0 \times 10^{3} \downarrow$ \\
\hline & AOW (50\%) & & $1.8 \times 10^{8}$ & $1.1 \times 10^{8}$ & $1.9 \times 10^{6}$ \\
\hline & AOW (25\%) & & $1.7 \times 10^{8}$ & $1.1 \times 10^{8}$ & $2.0 \times 10^{8}$ \\
\hline \multirow{4}{*}{$\begin{array}{l}\text { E. coli } \\
\text { (Ec) }\end{array}$} & 生理食塩数 & \multirow{4}{*}{$8.0 \times 10^{7}$} & $8.0 \times 10^{7}$ & $8.0 \times 10^{7}$ & $8.0 \times 10^{7}$ \\
\hline & AOW（原液） & & $1.0 \times 10^{3} \downarrow$ & $1.0 \times 10^{3} \downarrow$ & $1.0 \times 10^{3} \downarrow$ \\
\hline & AOW (50\%) & & $1.0 \times 10^{3} \downarrow$ & $1.0 \times 10^{3} \downarrow$ & $1.0 \times 10^{3} \downarrow$ \\
\hline & AOW (25\%) & & $4.0 \times 10^{3}$ & $1.2 \times 10^{3}$ & $1.0 \times 10^{3}$ \\
\hline \multirow{4}{*}{$\begin{array}{l}\text { S. enteritidis } \\
\text { (Se) }\end{array}$} & 生理食塩液 & \multirow{4}{*}{$1.9 \times 10^{8}$} & $2.0 \times 10^{8}$ & $1.9 \times 10^{8}$ & $2.2 \times 10^{8}$ \\
\hline & AOW（原液） & & $9.0 \times 10^{5}$ & $1.0 \times 10^{3} \downarrow$ & $1.0 \times 10^{3} \downarrow$ \\
\hline & AOW $(50 \%)$ & & $1.0 \times 10^{7}$ & $1.0 \times 10^{3} \downarrow$ & $1.0 \times 10^{3} \downarrow$ \\
\hline & AOW (25\%) & & $1.0 \times 10^{8}$ & $9.0 \times 10^{7}$ & $8.4 \times 10^{7}$ \\
\hline
\end{tabular}

くり返し 2 回実験を行い, その平均值を示した. 以下の表も同様. 
表 2 歯周病原菌に対するAOW の殺菌効果と希釈による影響

\begin{tabular}{|c|c|c|c|c|c|}
\hline \multirow{2}{*}{ 細菌の種類 } & \multirow{2}{*}{$\mathrm{AOW}$ 濃度 } & \multicolumn{4}{|c|}{ 生 残 菌 数 (個)) } \\
\hline & & $0 \mathrm{~min}$ & $1 \mathrm{~min}$ & $5 \mathrm{~min}$ & $10 \mathrm{~min}$ \\
\hline \multirow{4}{*}{$\begin{array}{l}\text { A. actinomycetemcomitans } \\
\mathrm{Y} 4\end{array}$} & 生理食塩液 & \multirow{4}{*}{$5.0 \times 10^{8}$} & $5.0 \times 10^{8}$ & $4.9 \times 10^{8}$ & $4.4 \times 10^{8}$ \\
\hline & AOW（原液） & & $1.0 \times 10^{3} \downarrow$ & $1.0 \times 10^{3} \downarrow$ & $1.0 \times 10^{3} \downarrow$ \\
\hline & AOW $(50 \%)$ & & $1.0 \times 10^{3} \downarrow$ & $1.0 \times 10^{3} \downarrow$ & $1.0 \times 10^{3} \downarrow$ \\
\hline & AOW (25\%) & & $1.0 \times 10^{3} \downarrow$ & $1.0 \times 10^{3} \downarrow$ & $1.0 \times 10^{3} \downarrow$ \\
\hline \multirow{4}{*}{$\begin{array}{l}\text { A. actinomycetemcomitans } \\
29522 \quad \text { (Aa) }\end{array}$} & 生理食塩液 & \multirow{4}{*}{$4.6 \times 10^{8}$} & $4.6 \times 10^{8}$ & $4.6 \times 10^{8}$ & $4.7 \times 10^{8}$ \\
\hline & AOW（原液） & & $1.0 \times 10^{3} \downarrow$ & $1.0 \times 10^{3} \downarrow$ & $1.0 \times 10^{3} \downarrow$ \\
\hline & AOW (50\%) & & $1.0 \times 10^{3} \downarrow$ & $1.0 \times 10^{3} \downarrow$ & $1.0 \times 10^{3} \downarrow$ \\
\hline & AOW (25\%) & & $1.0 \times 10^{3} \downarrow$ & $1.0 \times 10^{3} \downarrow$ & $1.0 \times 10^{3} \downarrow$ \\
\hline \multirow{4}{*}{$\begin{array}{l}\text { P. gingivalis } \\
381\end{array}$} & 生理食塩液 & \multirow{4}{*}{$3.5 \times 10^{8}$} & $3.4 \times 10^{8}$ & $3.4 \times 10^{8}$ & $3.3 \times 10^{8}$ \\
\hline & AOW（原液） & & $1.0 \times 10^{3} \downarrow$ & $1.0 \times 10^{3} \downarrow$ & $1.0 \times 10^{3} \downarrow$ \\
\hline & AOW (50\%) & & $1.0 \times 10^{3} \downarrow$ & $1.0 \times 10^{3} \downarrow$ & $1.0 \times 10^{3} \downarrow$ \\
\hline & AOW (25\%) & & $1.0 \times 10^{3} \downarrow$ & $1.0 \times 10^{3} \downarrow$ & $1.0 \times 10^{3} \downarrow$ \\
\hline \multirow{4}{*}{$\begin{array}{l}\text { P. gingivalis } \\
33277 \quad(\mathrm{Pg})\end{array}$} & 生理食塩液 & \multirow{4}{*}{$3.0 \times 10^{8}$} & $2.9 \times 10^{8}$ & $2.9 \times 10^{8}$ & $2.8 \times 10^{8}$ \\
\hline & AOW（原液） & & $1.0 \times 10^{3} \downarrow$ & $1.0 \times 10^{3} \downarrow$ & $1.0 \times 10^{3} \downarrow$ \\
\hline & AOW (50\%) & & $1.0 \times 10^{3} \downarrow$ & $1.0 \times 10^{3} \downarrow$ & $1.0 \times 10^{3} \downarrow$ \\
\hline & AOW (25\%) & & $1.0 \times 10^{3} \downarrow$ & $1.0 \times 10^{3} \downarrow$ & $1.0 \times 10^{3} \downarrow$ \\
\hline \multirow{4}{*}{$\begin{array}{l}\text { F. nucleatum } \\
23726 \quad \text { (Fn) }\end{array}$} & 生理食塩液 & \multirow{4}{*}{$3.1 \times 10^{8}$} & $3.1 \times 10^{8}$ & $3.1 \times 10^{8}$ & $3.1 \times 10^{8}$ \\
\hline & AOW（原液） & & $1.0 \times 10^{3} \downarrow$ & $1.0 \times 10^{3} \downarrow$ & $1.0 \times 10^{3} \downarrow$ \\
\hline & AOW (50\%) & & $1.0 \times 10^{3} \downarrow$ & $1.0 \times 10^{3} \downarrow$ & $1.0 \times 10^{3} \downarrow$ \\
\hline & AOW (25\%) & & $1.0 \times 10^{3} \downarrow$ & $1.0 \times 10^{3} \downarrow$ & $1.0 \times 10^{3} \downarrow$ \\
\hline
\end{tabular}

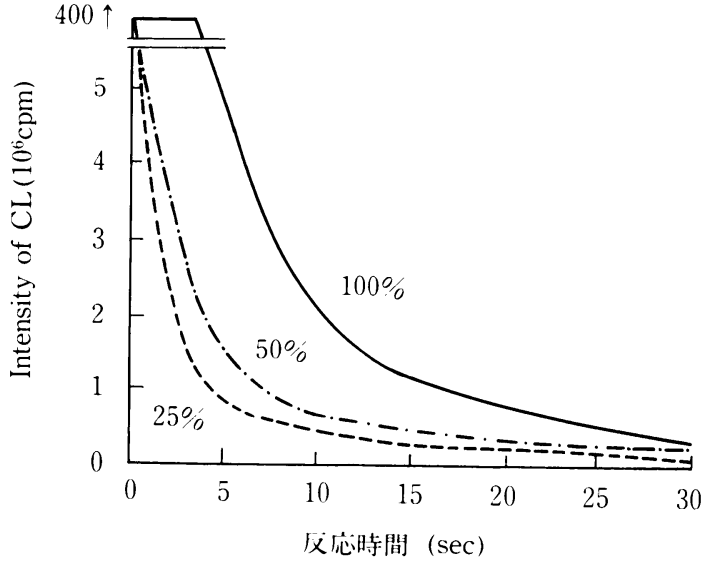

図 1 AOW に含有されているラジカルについて くり返し 2 回実験を行い，その平均值を示した
AOW 原液および AOW 50\% 希釈液，25\%希釈 液は, $\mathrm{AOW}$ 濃度依存的に CL 反応性のラジカル を検出することができた。しかし，10\%血清や 10\%唾液を添加することによって CL 反応は消失 しラジカルの減少することを示した。

2 ) $\mathrm{pH}$, 酸化還元電位, $\mathrm{HClO}$ 量の変化 (表 5 ) $\mathrm{AOW}$ の $\mathrm{pH}(\mathrm{AOW}$ 原液； $\mathrm{pH} 2.5 ）$ は, AOW $25 \%$ 希釈液で $\mathrm{pH} 6.92$ となり，希釈とともに中性 に近づく傾向を示した。 また，AOW 原液におけ る $1 \%$ 血清および $10 \%$ 唾液の添加では $\mathrm{pH}$ の変 化は少なかったが，10\%血清の添加では pH 5.60 と中性に近づく傾向を示した。

AOW の酸化還元電位 $(\mathrm{AOW}$ 原液 $; 1144.8$ $\mathrm{mV})$ は, $25 \%$ 希釈でも $1000.6 \mathrm{mV}$ の值を示した。 さらに，AOW 原液において $1 \%$ 血清および $10 \%$ 唾液を添加しても $1,070 \mathrm{mV}$ 付近の值を示した 
表 3 歯周病原菌への AOW 100\%の殺菌効果における血清および唾液の添加による影響

\begin{tabular}{|c|c|c|c|c|c|}
\hline \multirow{2}{*}{ 紐菌の種類 } & \multirow{2}{*}{ 血清および唾液濃度一 } & \multicolumn{4}{|c|}{ 生 残 菌 数 (個)) } \\
\hline & & $0 \mathrm{~min}$ & $1 \mathrm{~min}$ & $5 \mathrm{~min}$ & $10 \min$ \\
\hline \multirow{4}{*}{$\begin{array}{l}\text { A. actinomycetemcomitans } \\
\mathrm{Y} 4 \quad(\mathrm{Aa})\end{array}$} & 生理食塩液 & \multirow{4}{*}{$5.0 \times 10^{8}$} & $5.0 \times 10^{8}$ & $4.9 \times 10^{8}$ & $4.4 \times 10^{8}$ \\
\hline & 血清（1％） & & $2.8 \times 10^{4}$ & $1.0 \times 10^{3} \downarrow$ & $1.0 \times 10^{3} \downarrow$ \\
\hline & Ifll清（10\%） & & $4.5 \times 10^{8}$ & $4.8 \times 10^{8}$ & $4.1 \times 10^{8}$ \\
\hline & 唾液（10\%） & & $1.0 \times 10^{3} \downarrow$ & $1.0 \times 10^{3} \downarrow$ & $1.0 \times 10^{3} \downarrow$ \\
\hline \multirow{4}{*}{$\begin{array}{l}\text { A. actinomycetemcomitans } \\
29522 \quad \text { (Aa) }\end{array}$} & 生理食塩液 & \multirow{4}{*}{$4.6 \times 10^{8}$} & $4.6 \times 10^{8}$ & $4.6 \times 10^{8}$ & $4.7 \times 10^{8}$ \\
\hline & 血清（1％） & & $1.0 \times 10^{3} \downarrow$ & $1.0 \times 10^{3} \downarrow$ & $1.0 \times 10^{3} \downarrow$ \\
\hline & 血清（10\%） & & $2.9 \times 10^{8}$ & $2.4 \times 10^{8}$ & $2.2 \times 10^{8}$ \\
\hline & 唾液（10\%） & & $1.0 \times 10^{3} \downarrow$ & $1.0 \times 10^{3} \downarrow$ & $1.0 \times 10^{3} \downarrow$ \\
\hline \multirow{4}{*}{$\begin{array}{l}P . \text { gingivalis } \\
381\end{array}$} & 生理食塩液 & \multirow{4}{*}{$3.5 \times 10^{8}$} & $3.4 \times 10^{8}$ & $3.4 \times 10^{8}$ & $3.3 \times 10^{8}$ \\
\hline & 血清（1％） & & $1.0 \times 10^{3} \downarrow$ & $1.0 \times 10^{3} \downarrow$ & $1.0 \times 10^{3} \downarrow$ \\
\hline & 血清（10\%） & & $2.7 \times 10^{8}$ & $1.9 \times 10^{8}$ & $2.3 \times 10^{8}$ \\
\hline & 唾液（10\%） & & $1.0 \times 10^{3} \downarrow$ & $1.0 \times 10^{3} \downarrow$ & $1.0 \times 10^{3} \downarrow$ \\
\hline \multirow{4}{*}{$\begin{array}{ll}P . \text { gingivalis } & \\
33277 & (\mathrm{Pg})\end{array}$} & 生理食塩液 & \multirow{4}{*}{$3.0 \times 10^{8}$} & $2.9 \times 10^{8}$ & $2.9 \times 10^{8}$ & $2.8 \times 10^{8}$ \\
\hline & 血清（1％） & & $1.0 \times 10^{3}$ & $1.0 \times 10^{3} \downarrow$ & $1.0 \times 10^{3} \downarrow$ \\
\hline & 血清（10\%） & & $2.4 \times 10^{8}$ & $1.9 \times 10^{8}$ & $2.4 \times 10^{8}$ \\
\hline & 唾液（10\%） & & $1.0 \times 10^{3} \downarrow$ & $1.0 \times 10^{3} \downarrow$ & $1.0 \times 10^{3} \downarrow$ \\
\hline \multirow{4}{*}{$\begin{array}{l}\text { F. nucleatum } \\
23726 \quad \text { (Fn) }\end{array}$} & 生理食塩液 & \multirow{4}{*}{$3.1 \times 10^{8}$} & $3.1 \times 10^{8}$ & $3.1 \times 10^{8}$ & $3.1 \times 10^{8}$ \\
\hline & 血清（1\%） & & $5.4 \times 10^{7}$ & $1.0 \times 10^{7}$ & $1.4 \times 10^{6}$ \\
\hline & 血清（10\%） & & $3.3 \times 10^{8}$ & $2.4 \times 10^{8}$ & $9.0 \times 10^{7}$ \\
\hline & 唾液（10\%） & & $6.6 \times 10^{5}$ & $2.4 \times 10^{5}$ & $1.2 \times 10^{5}$ \\
\hline
\end{tabular}

が，10\%血清の添加では $479.0 \mathrm{mV}$ と低下した. $\mathrm{AOW}$ の $\mathrm{HClO}$ 量 $(\mathrm{AOW}$ 原液；19.4 ppm) は, AOW 25\%希釈でも $4.5 \mathrm{ppm}$ 含まれていた。さら に，AOW 原液における $10 \%$ 唾液の添加で 6.0 ppm, 1\%血清の添加で $0.7 \mathrm{ppm}$ 含まれていたが, 10\%血清の添加では検出できなかった。

\section{考察}

口腔内は数多くの細菌が生息し, 細菌学的検索 から，いくつかのグラム陰性嫌気性桿菌（総括し て蔽周病原菌）による感染が歯肉炎・歯周炎の発 症抢よび進行に関与していると考えられてい $3^{12)}$. またメチシリン耐性黄色ブドウ球菌 (MRSA) 感染症や HIV, 血清肝炎などの院内感 染も問題となっている ${ }^{13)}$.
一方，数年前から食塩水の電気分解により得ら れる強酸性水が，広範囲の微生物に対して殺菌効 果を示すことが示され ${ }^{2 \sim 10)}$, 日常臨床への応用が 期待されている.

本実験では，歯周疾患に対する応用へのアプ ローチとして, Sa, Ec, Se を対照細菌群として 歯 周病原菌群 $\mathrm{Aa}, \mathrm{Pg}, \mathrm{Fn}$ に対する $\mathrm{AOW}$ の殺菌力 を検討し，さらに口腔内でもその殺菌力が保持さ れるかをあきらかにする目的で, 血清や唾液添加 における殺菌効果への影響も検討した。

AOW 原液は, Sa, Ec, Aa 群, Pg 群, Fn の生 残菌を 1 分以内に $10^{8}$ から $10^{3}$ 以下と著しく減少 させ, 強力な殺菌効果を示した. Se も 1 分以上 5 分以内に生残菌が $10^{8}$ から $10^{6}$ 付近となり, 比較的 効果が認められた。

また, AOW を希䣋すると, 歯周病原菌群の $\mathrm{Aa}$ 
表 $4 \mathrm{AOW}$ の殺菌力の経時的变化

\begin{tabular}{|c|c|c|c|c|}
\hline \multirow{2}{*}{$\mathrm{AOW}$ 保存日数・濃度 } & \multicolumn{4}{|c|}{ 生 残 菌 数 (個) } \\
\hline & $0 \mathrm{~min}$ & $1 \mathrm{~min}$ & $5 \mathrm{~min}$ & $10 \mathrm{~min}$ \\
\hline 生理食塩液 & \multirow{4}{*}{$5.0 \times 10^{8}$} & $5.0 \times 10^{8}$ & $4.9 \times 10^{8}$ & $4.4 \times 10^{8}$ \\
\hline AOW（調製直後；原液） & & $1.0 \times 10^{3} \downarrow$ & $1.0 \times 10^{3} \downarrow$ & $1.0 \times 10^{3} \downarrow$ \\
\hline AOW（調製直後；50\%） & & $1.0 \times 10^{3} \downarrow$ & $1.0 \times 10^{3} \downarrow$ & $1.0 \times 10^{3} \downarrow$ \\
\hline AOW（調製直後：25\%） & & $1.0 \times 10^{3} \downarrow$ & $1.0 \times 10^{3} \downarrow$ & $1.0 \times 10^{3} \downarrow$ \\
\hline 生理食塩液 & \multirow{4}{*}{$4.8 \times 10^{8}$} & $4.8 \times 10^{8}$ & $4.8 \times 10^{8}$ & $5.0 \times 10^{8}$ \\
\hline AOW（調製 8 週後；原液） & & $1.0 \times 10^{3} \downarrow$ & $1.0 \times 10^{3} \downarrow$ & $1.0 \times 10^{3} \downarrow$ \\
\hline AOW（調製 8 週後； $50 \% ）$ & & $1.0 \times 10^{3} \downarrow$ & $1.0 \times 10^{3} \downarrow$ & $1.0 \times 10^{3} \downarrow$ \\
\hline AOW（調製 8 週後；25\%） & & $1.0 \times 10^{3} \downarrow$ & $1.0 \times 10^{3} \downarrow$ & $1.0 \times 10^{3} \downarrow$ \\
\hline 生理食塩液 & \multirow{4}{*}{$5.1 \times 10^{8}$} & $5.0 \times 10^{8}$ & $4.9 \times 10^{8}$ & $5.1 \times 10^{8}$ \\
\hline AOW（調製 15 週後；原液） & & $1.0 \times 10^{3} \downarrow$ & $1.0 \times 10^{3} \downarrow$ & $1.0 \times 10^{3} \downarrow$ \\
\hline AOW（調製 15 週後；50\%） & & $1.0 \times 10^{3} \downarrow$ & $1.0 \times 10^{3} \downarrow$ & $1.0 \times 10^{3} \downarrow$ \\
\hline AOW（調製 15 週後；25\%） & & $1.0 \times 10^{3} \downarrow$ & $1.0 \times 10^{3} \downarrow$ & $1.0 \times 10^{3} \downarrow$ \\
\hline 生理食塩液 & \multirow{4}{*}{$5.0 \times 10^{8}$} & $5.0 \times 10^{8}$ & $5.0 \times 10^{8}$ & $5.0 \times 10^{8}$ \\
\hline AOW（調製 21 週後；原液） & & $1.0 \times 10^{3} \downarrow$ & $1.0 \times 10^{3} \downarrow$ & $1.0 \times 10^{3} \downarrow$ \\
\hline AOW（調製 21 週後：50\%） & & $1.0 \times 10^{3} \downarrow$ & $1.0 \times 10^{3} \downarrow$ & $1.0 \times 10^{3} \downarrow$ \\
\hline AOW（調製 21 週後：25\%） & & $1.0 \times 10^{4}$ & $1.0 \times 10^{3} \downarrow$ & $1.0 \times 10^{3} \downarrow$ \\
\hline
\end{tabular}

表 5 各条件下での AOW の性質への検討

\begin{tabular}{lccc}
\hline \multicolumn{1}{c}{ 使用条件 } & $\mathrm{pH}$ & $\begin{array}{c}\text { 酸化還元電位 } \\
(+\mathrm{mV})\end{array}$ & $\begin{array}{c}\mathrm{HClO} \text { 量 } \\
(\mathrm{ppm})\end{array}$ \\
\hline 生理食塩水 & 7.13 & 467.5 & 検出できず \\
$\mathrm{AOW}$ (原液) & 2.52 & 1144.8 & 19.4 \\
$\mathrm{AOW}(50 \%)$ & 6.50 & 1014.4 & 12.7 \\
$\mathrm{AOW}(25 \%)$ & 6.92 & 1006.6 & 4.5 \\
$\mathrm{AOW}$ (原液) $+1 \%$ 血清 & 2.61 & 1072.3 & 0.7 \\
$\mathrm{AOW}$ (原源) $+10 \%$ 血清 & 5.60 & 479.0 & 検出できず \\
$\mathrm{AOW}$ (原液) $+10 \%$ 唾液 & 2.71 & 1070.4 & 6.0 \\
\hline
\end{tabular}

群, Pg 群, Fn に対しては AOW 25\% 希釈液で も強力な殺菌効果を示し，これらの菌は比較的殺 菌されやすいことがわかった。一方, 対照細菌群 の $\mathrm{Sa}, \mathrm{Se}$ に対しては，AOW を $25 \%$ に希釈する とほとんど殺菌効果が失われ, Ec に対しても殺菌 力が低下したので, AOW の歯周病原菌群に対す る殺菌は, 今回用いた対照細菌群に対してょり大 きく作用することが分かった。

この結果から, 日常臨床においては歯周病の予
防または治療に AOW 原液の使用が効果的であ ることが示唆された。

AOW 原液に血清 1\%や唾液 10\%を添加した ところ, Pg 群に対して添加前と同様の傾向を示 し, 強力な殺菌効果にも影響しなかった. Aa 群へ の強力な殺菌効果にも影響は少なかったが，Y4 株では血清 $1 \%$ 添加で 1 分後 $10^{4}$ の菌が生残して おり，株差による若干の違いも認められた。しか し，Fn に対しては血清 1\%や唾液 10\%の添加に 
よって 10 分後でも $10^{5}$ 以上の菌が生残し, 殺菌効 果の減少が見られた.また，血清 10\%の添加では， 3 菌種とも生残菌の減少をほとんど認めず, AOW の殺菌作用は消失した。

強電解水の殺菌効果に唾液蛋白質などの有機物 の存在が影響を及ぼす報告6.9)もあり，血清や唾液 の蛋白質濃度が高くなるに従い殺菌効果が消失す る本実験でも同様のことが考えられた。さらに血 清や唾液を添加した際, Aa 群, Pg 群に比べ Fn が殺菌効果に抵抗性を示したことは, 菌種や菌株 の表層構造の違いによるほか, 血清や多形核白血 球の殺菌作用に抵抗性を示すことにも関連すると 推察された。

In vitro ながらこれらの結果から, 日常臨床に おいて, AOW は歯周疾患などの口腔内疾患の予 防・治療への応用の可能性を示した。しかし, 大 量に血液の存在する部位での使用には殺菌力低下 の点で注意が必要であると考えられた。

次に, AOW の殺菌力の持続性について検討し た結果, $4{ }^{\circ} \mathrm{Cで}$ 庶光ポリ容器保存した $\mathrm{AOW}$ は, 21 週後でも調製直後の $\mathrm{AOW}$ と同様の殺菌力を 認めた。 AOW の保存状況の違いによる酸化還元 電位上溶存塩素濃度の経時的関係を測定し, $4{ }^{\circ} \mathrm{C}$, 遮光密封容器保存では 38 日後でも安定である7 ことも報告されており, $4{ }^{\circ} \mathrm{C}$, 遮光密封容器保存 であれば 21 週後でもかなり殺菌効果を保つこと ができると思われた。

また，本実験で行った各条件の AOW のラジカ ルを CL 反応にて測定した結果, $\mathrm{AOW}$ 中のラジ カルは AOW 濃度に依存していった。しかし, 血 清や唾液を添加するとこの反応は 1 秒以内にほと んど消失してしまい, ラジカルの組織傷害性を考 えると, 添加直後の消失は口腔内使用の際の安全 性に関連すると思われるが, 今後, 口腔内組織へ の傷害性の検討も必要であると考えられた。

以上の結果と各条件の AOW の性質を比較し て検傠すると， AOW 25\%希釈液では $\mathrm{pH}$ が中性 に近づくにもかかわらず殺菌効果を示したことか ら, 低い $\mathrm{pH}$ が直接的に殺菌効果を示すことは否 定できた。また，1\%血清もしくは 10\%唾液の添 加によって CL 反応がほぼ完全に消失したこと は, ラジカルも殺菌効果の主体にならないと考え
られた。

$\mathrm{HClO}$ 量は $10 \%$ 血清の添加ではほとんど検出 できなかったのに対し，1\%血清の添加において $0.7 \mathrm{ppm}$ 検出された。また酸化還元電位は殺菌効 果に比例した結果となった。酸化還元電位や溶存 塩素ガス濃度は平衡状態にあることを考えるとお そらく酸化還元電位や, $\mathrm{HClO}$, 溶存塩素ガスが安 定した殺菌効果に関与すると考えられた。

\section{ま と め}

AOW の歯周病原菌に対する殺菌効果を検討 し，また口腔内環境における効果をあきらかにす る目的で実験を行い, 以下の結論を得た。

1. $\mathrm{AOW}$ の殺菌効果は, $\mathrm{Sa}, \mathrm{Ec}, \mathrm{Se}$ と比較し て歯周病原菌（Aa, Pg, Fn）で効果が大きいこと が分かった。さらにその殺菌効果は瞬時に起こる と考えられた。

2. AOW の殺菌効果への血清の影響は, 血清 $1 \%$ の添加で Aa 群および Pg 群に対する殺菌効 果への影響がほとんどなかったのに比べ, Fnに 対しては著しい殺菌効果の減少が認められた。 ま た, 血清 10\%の添加で, いずれの菌に対しても殺 菌力は完全に消滅した。したがって，AOW は血 液が存在する部位での歯周病予防または治療を目 的とした使用には不向き，もしくは頻繁な洗浄を 必要とすると考えられた。

3. AOW の殺菌効果への唾液の影響は, Aa 群 および Pg 群では唾液 10\%の添加で殺菌効果に 影響がなく， 口腔内における歯周病巣局所の消毒 には有効であろうと考えられた。しかし，Fnに対 しては殺菌効果の低下を認めたことから, 口腔内 使用の際には考慮が必要であると思われた。

4. $4{ }^{\circ} \mathrm{C}$, 遮断密封したポリ容器中での保存に よるアクア酸化水の殺菌力は, 21 週, 約 5 力月以 上経過しても持続した。

5. 安定した殺菌効果を示す因子として, 酸化 還元電位や $\mathrm{HClO}$ の関与が示唆された.

以上の結果から, AOW が歯周疾患など口腔内 疾患の予防・治療に有効である可能性が示された。

稿を終えるにあたり，器械をご供与下さいました東 
京歯材社, 三浦電子株式会社ならびに日本歯科大学強 酸性水研究グループをとりまとめていただきました 日本歯科大学歯周病学教室鴨井久一教授に厚くお礼 申し上げます。

\section{参考文献}

1）清水義信, 古沢利武：電解による酸化電位水の 殺ウィルス，殺細菌および殺真菌の作用，歯科 ジャーナル，36：1055-1060，1992.

2）岩沢篤郎, 中村良子, 岡田 淳, 水野徳次：ア クア酸化水の抗ウィルス効果. 臨床と微生物, 20：231-236, 1993.

3）岩沢篤郎，中村良子：アクア酸化水の抗微生物 効果. エンテロウィルス・抗酸菌・真菌に対す る作用. 臨床と微生物, 20：469-473，1993.

4）岩沢篤郎, 中村良子, 水野徳次：臨床分離株に 対するアクア酸化水の効果. 日環誌, 8：11-16, 1993.

5）岩沢篤郎, 中村良子, 中村國衛, 村井哲也：ア クア酸化水の殺菌効果に対する検討. 薬理と臨 床, 3：1555-1562, 1993 .

6）酒井敏博, 芝 燁彦, 万代倫嗣, 中根文誉, 飯 沼浩之, 迎 和彦, 三浦頡剛, 池田益夫, 芝 紀 代子, 水野徳次: OXILYZER による電解水の 歯科領域への応用 第一報 使用条件について。 補綴誌，37：920-927，1993.

7）芝 燁彦, 酒井敏博, 塚崎弘明, 尾関雅彦, 中 根浩之, 鈴木哲史, 加瀬智夏, 三浦頡剛, 小花
照雄, 飯沼浩之: 電解水の歯科領域への応用. 歯界展望, 84：931-941，1994.

8）西田哲也, 辻 康男, 菅井健二, 音琴淳一, 吉 沼直人，鈴木邦治，村井正大：アクア酸化水の プラーク形成抑制効果. 日歯周誌, 35：692-697, 1994.

9）浅井昭士郎，山村正次，野田充宏，高瀬市将, 平田健一, 滝 永一, 南 晋介, 青野正男, 磯 貝昌彦，並河 勇：酸化電位水による殺菌効果 と変異原性の検討. 歯基礎誌, 37：152-161, 1995.

10）奥田禮一，笹崎弘已，兼平正史，岡部太一，阿 部 敏, 田上篤, 岩松洋子, 宮 豊, 清水 義信：形態変化から観た酸化電位水の殺菌効 果. 日歯保誌, 37 :755-765, 1994.

11) 日本化学会編：実験化学講座 15 分析. 丸善(東 京) 229, 1991.

12) Page, R, C. and Schroeder, H.F. : Periodontitis in man and other animals. Karber, basel. : 239-346, 1982.

13）浅利誠志, 妙中信之：MRSA の教訓と今後の院 内感染防止対策 院内感染防止の立場から見た 適切な消毒剂の使用法. 最新医学, 49:10091014, 1994 .

別刷請求先：荻原和孝:

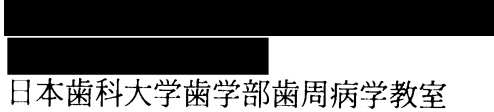

